\title{
Konflik Tenurial di Pulau Padang dan Isolasi Ekonomi Lokal ${ }^{1}$
}

Ahmad Ar Rozy, Rio Belvage, dan Oka Karyanto²

\begin{abstract}
Abstraksi
Dengan menggunakan data-data etnografi dan dokumentasi sejarah. Studi ini berupaya mengungkapkan konflik tenurial di Pulau Padang yang memiliki dampak isolasi terhadap pengembangan ekonomi lokal. Dalam ruang lingkup studi ini, lahan tenurial yang berisi tentang seperangkat aturan ( the set of rules ) yang menentukan hak akses setiap orang ( individu ) terhadap sumber daya alam tertentu telah dilanggar oleh kelompok dan jaringan industri pengolahan kayu yang tidak bertanggungjawab. Hasil penelitian ini menunjukkan realitas konflik muncul di permukaan karena status kuasa hukum, hak pengelolaan dan pemanfaatan jenis hutan, hak perkebunan, kemudian disertai pemanfaatan redistribusi. Diperparah dengan kondisi produk hukum yang carutmarut mengakibatkan status hukum tidak mempunyai peran penegakan keadilan, pembagian kerja, dan koridor pelestarian lingkungan alam tentang lahan gambut maupun aspek-aspek yang mendukung kelestarian ekosistem alam. Riset sosial multidisiplin ini menggunakan pendekatan sosiologi-sejarah dan antropologi struktural.
\end{abstract}

Kata kunci: konflik, tenurial, status hukum, industri kehutanan.

\begin{abstract}
Using ethnographic data and historical documentation. This study seeks to reveal tenurial conflicts in Padang Island that have an impact on isolation on local economic development. Within the scope of this study, tenure fields containing the set of rules that determine the access rights of individuals to specific natural resources have been violated by irresponsible groups and networks of wood processing industries. The results of this study indicate that conflicts arise on the surface because of the legal status, the right to manage and use of forest types, plantation rights, and then the utilization of redistribution. Compounded by the condition of legal products that lead to legal status does not have the role of law enforcement, division of labor, and corridors of conservation of the natural environment on peatlands and aspects that support the sustainability of natural ecosystems. This multidisciplinary social research uses a historical-sociology approach and structural anthropology.
\end{abstract}

Keywords: conflict, tenure, legal status, forest industry

\section{A. Pendahuluan}

Manusia kontemporer saat ini mungkin sudah lupa cita-cita perbaikan hidup di antara sesama masyarakat dikarenakan mengalami kealphaan pada hubungan sosial yang termaktub pada sejarah manusia (human history). Persepsi lahan dengan kepemilikannya mengalami perubahan konstitusi yang cukup panjang dari masyarakat pra-kapital menuju masyarakat kapitalis. Perihal ini disebabkan perubahan komunalitas dan pertautan antara hukum adat dengan hukum positif (institusionalmodernistik). Pada kerangka keutuhan lahan gambut sebagaimana dicatat oleh Driessen pada tahun 1976 masih memiliki luas 9,7 juta ha di kawasan Sumatera Timur termasuk area Riau beserta Pulau Padang dan Kepulauan Meranti. Pada tahun 1981, perincian luas lahan gambut menurun dengan angka 8,9 juta ha berdasarkan perhitungan

\footnotetext{
1 Untuk mengutip artikel ini: Ar Rozy, Belvage dan Karyanto. 2018. 'Konflik Tenurial di Pulau Padang dan Isolasi Ekonomi Lokal'. Jurnal Pemikiran Sosiologi 5 (1): 51-68.

${ }^{2}$ Ahmad Ar Rozy, Rio Belvage dan Oka Karyanto tergabung dalam tim peneliti riset sosial Kelompok Kerja Gambut di Pulau Padang Riau (2016-2017) kerjasama Fakultas Kehutanan UGM dan Badan Restorasi Gambut (BRG).
} 
Jurnal Pemikiran Sosiologi Volume 5 No. 1, 2018

Konflik Tenurial di Pulau Padang dan Isolasi Ekonomi Lokal Ahmad Ar Rozy, Rio Belvage, dan Oka Karyanto

Pusat Penelitian Tanah dan Agroklimat (Daryono 2009: 71 ). Pada era selanjutnya antara tahun 1997 hingga 2000, luas lahan gambut hanya 2,83 juta ha dengan kerusakan hutan lahan gambut di area Sumatera Timur dan Kepulauan utara Provinsi Riau. Perubahan penyempitan lahan gambut dalam kajian ini menitikberatkan pada studi intervensi manusia dan masyarakatnya dengan berbagai eskalasi konfliknya. Realitas konflik pada masyarakat prakapital didasarkan pada krisis properti terhadap keberlangsungan hidup, sedangkan dalam sosiologi masyarakat kapitalis suatu konflik terjadi karena kompetisi yang terlalu serius dengan mempertontonkan pencapaian yang tidak selalu dibutuhkan masyarakat kelas bawah. Atau dapat terjadi juga penekanan produksi dengan upah yang tidak setara atau kondisi psikologis tenaga kerja yang tidak dipikirkan penguasa modal. Akan tetapi pola-pola umum yang termaktub dalam kronologi sejarah berupa pencaplokan lahan garapan milik buruh tani atau buruh perkebunan oleh transaksi industrial.

Dalam catatan etnografi masyarakat Pulau Padang maupun para pendatang dari pulau-pulau tetangga memiliki pekerjaan memotong kayu (mbalak kayu). Sejak tahun 1970an telah terjadi kerja mbalak yang merupakan jasa pemotongan kayu ilegal karena menjadi kebutuhan ekonomi pasar gelap (black market) di belantara hutan kepulauan Riau. Hasil pemotongan kayu dipasok melalui jual-beli dan pengemasan kirim oleh taukeh-taukeh Tionghoa yang bermukim di Pulau Padang. Pengemasan kayu kemudian dikirim melalui angkutan transportasi menuju area Singapura atau perusahaan pengolahan kayu dan meubel. Pada kurun waktu yang sama, P.T Satria Perkasa Agung dari Grup Kiat Indah telah merintis operasionalisasi mode manufaktur di Pulau Padang (Belvage 2017 : 4 ).

Mode produksi automasi manufaktur telah mengikis metode manual mbalak kayu, situasi masyarakat desa Mengkirau dan desa sekitar bekerja mbalak di pulaunya sendiri, kemudian hasilnya diserahkan kepada pengguna (user) seorang taukeh tenar bernama Locat. Perubahan sosial mengitari dalam lingkaran sejarah hingga kemudian berganti ketika ketersediaan kayu alam mulai menyusut di sebagian wilayah desa. Aktivitas mbalak pun mulai berangsur sirna dari pilihan pekerjaan penduduk setempat, hingga pada tahun 2013 hanya tersisa Desa Tanjung Padang yang masih melakukan pekerjaan mbalak. Maka dari itu, para masyarakat dari desa lain mulai berganti pekerjaan dengan mengadu nasib dengan melakukan perantauan di Malaysia. Sedangkan golongan masyarakat yang menetap berpindah pada usaha perkebunan karet dan penanaman sagu (Belvage 2017: 4 ).

Pada sisi lain Malaysia menjadi jazirah idaman bagi masyarakat Pulau Padang di mana mbalak kayu dan berkebun tidak dapat memenuhi kebutuhan primer dan sekunder. Catatan etnografi menuturkan pertengahan 1980an sebagian penghuni Pulau Padang merantau ke Malaysia dengan bekerja membersihkan saluran air, kuli bangunan dan tenaga perkebunan (Belvage 2017: 4 ). Keputusan merantau terbilang dalam status yang tidak memiliki izin resmi dari otoritas imigrasi dikarenakan aturan kedua negara cukup longgar dan tidak ada pengawasan yang berarti disebabkan kondisi sosial dengan ungkapan ' sama-sama tahu '. Dalam keterangan etnografis, pemerintah Malaysia mempunyai maksud untuk meningkatkan jumlah 
penduduk dan pasokan tenaga kerja dalam skala industri manufaktur sehingga perantauan dari mana pun diterima untuk bekerja sebagai tenaga buruh. Sementara di perkampungan Pulau Padang, operasionalisasi tambang minyak terus mengalami masa-masa eksploitatif di bawah perusahaan kendali birokrasi dan aparat Orde Baru, hingga kemudian dilanjutkan pada rezim pengusaha dan pemerintahan lokal.

Para perantau muda dari Pulau Padang menuju Malaysia umumnya menjadi kuli kontrak sehingga sampai berkeluarga dan berpindah status kewarganegaraan di Negeri Jiran tersebut. Sedangkan bagi yang memilih menetap di perkampungan umumnya bekerja sebagai tenaga perkebunan. Penyelidikan etnografis menyebutkan salah satu kampung di Pulau Padang yang melanjutkan tradisi perantauan ke Malaysia ialah Desa Sungai Anak Kamal. Wilayah desa baru ini memisahkan secara kolektif dari induk desa lama dan umumnya warganya berasal dari keturunan Jawa Kebumen.

Lahan kebun karet menjadi ruang pekerjaan dan budaya perkebunan bagi penduduk setempat dengan pola perluasan lahan di pesisir yang semakin hari mengikuti pola pemukiman permanen. Temuan etnografi menyebutkan ada dua desa dengan pola tersebut, yakni Desa Mengkirau dan Desa Sungai Anak Kamal. Era dahulu kampung lama di dua desa itu berada di dekat laut. Setelah air asin menerjang masuk pada kanal-kanal anak sungai, seiring perkembangan waktu mereka pindah semakin ke dalam kemudian membuka hutan untuk dijadikan tempat tinggal (Belvage 2017: 4 ).
Pada catatan etnografi di atas menimbulkan dua konsep sosial yang saling berpolemik yakni antara lahan kepemilikan ( land tenure ) dan kondisi terpinggirkan sehingga jalan perantauan menjadi penyelesaian utama. Dua konsep sosial ini dalam globalisasi dan era keterbukaan dianggap tidak fair dalam memenuhi kesetaraan masyarakat dunia. Diikuti dengan aspek-aspek pluralitas penduduk kepulauan sehingga segregasi etnisitas membatasi gotong royong penduduk.

Dalam artikel ini, peneliti sosiologi-sejarah dan antropologi berusaha menyelidiki; seperti apa polapola dan jenis konflik yang terjadi di Pulau Padang ? Lalu seperti apa cara berpikir untuk melakukan penyelesaian dan pengembangan ekonomi lokal ? Jika meminjam pertanyaan filsafat nilai (aksiologi) "mengapa terjadi konflik berkepanjangan" dan "mengapa tujuan keseimbangan alam dan keadilan sosial tidak kunjung terjadi di negeri kepulauan." Apakah persepsi capaian kesejahteraan antara berbagai profesi dan kelas sosial di masyarakat tidak kunjung didapatkan sehingga menimbulkan konflik berkepanjangan dan dampak kesalahan mengurusi potensi keanekaragaman hayati.

\section{B. Metode Penelitian}

Pengumpulan data lapangan di atas dilakukan oleh peneliti bidang antropologi dan sosiologi dengan lokasi desa Mengkirau, desa Mengkopot, dan Tanjung Kulim di Pulau Padang pada tahun 20162017. Untuk menggambarkan kehidupan masyarakat setempat maka menggunakan metode etnografi dari observasi (Rio Haykal Belvage dan Hendra Mahulae, 2016). Kemudian dilakukan pengumpulan data (collecting data) bersama 
Jurnal Pemikiran Sosiologi Volume 5 No. 1, 2018

Konflik Tenurial di Pulau Padang dan Isolasi Ekonomi Lokal Ahmad Ar Rozy, Rio Belvage, dan Oka Karyanto

dokumentasi dan naskah akademik hasil dari kajian kehutanan Indonesia. Proses observasi berupa mendefinisikan situasi (konteks), kebahasaan, objek, interaksi, dan perilaku. Sedangkan partisipasi berupa kondisi percakapan, reaksi, pemikiran, suasana, dan realisasi interaksi kepada individu lain. Pada tahap selanjutnya studi penggunaan literasi sejarah secara heuristik. Tahapan pengumpulan literatur merupakan aspek penting dalam proses dan tahap kajian ini sehingga pada tahap selanjutnya berkaitan dengan penggunaan literatur. Penggunaan literatur terdiri dari kategori teknis maupun non-teknis (Strauss and Corbin 2013: 39 ). Literatur teknis menyangkut laporan tentang kajian penelitian dan karya publikasi ilmiah dalam bentuk teoretis atau historis (Strauss and Corbin 2013: 39). Keseluruhan ini dapat digunakan sebagai bahan latar belakang yang merupakan usaha perbandingan bagi data-data yang telah dikumpulkan (Strauss and Corbin 2013: 39). Sedangkan literatur non-teknis merupakan kumpulan dari berbagai catatan dan rekaman sosial dalam bentuk dokumen laporan penelitian, naskah akademik, rekaman audio-visual, situs dan laman internet.

Sedangkan validasi data berdasarkan diferensiasi autentisitas sumber primer dan sumber sekunder yang meliputi : informan kunci (key informant) dan informan pendukung (supporting informant) disertakan catatan lapangan (field notes). Kemudian dibandingkan dengan kritik dokumentasi seperti kritik eksternal pada bentuk fisik sedangkan kritik internal pada segi orisinalitas konten (Hoopes 1979).

Pasca pengumpulan dan pengolahan data secara metodis maka langkah selanjutnya adalah analisis data representatif. Analisa ini berusaha melakukan komparasi dan adaptasi secara konseptual berdasarkan teori elaborasi antara antropologi, sejarah, dan sosiologi. Analisa ini melakukan fokus terhadap pola hubungan dan susunan kelompok beserta individu yang melingkupi sasaran struktur sosial. Meminjam langkah Claude Levi-Strauss, struktur dapat mencerminkan representasi kolektif beserta kesadaran lokal atau nasional (Pace 1978: 282).

\section{Kilas Balik Konflik Tenurial}

Lahan tenurial berdasarkan definisi kelembagaan FAO (Food Agricultural Organization) berisi tentang seperangkat aturan (the set of rules) yang menentukan hak akses oleh orang (individu) terhadap sumber daya alam tertentu, dan juga merupakan bentuk dukungan sosial dari hubungan ini (Herrera 2006: 9). Sistem penguasaan lahan di berikan yurisdiksi yang terdiri dari sekumpulan basis pranata sosial-ekonomi di mana lahan dapat digunakan sesuai kebutuhan pembangunan dan konservasi. Definisi ini mencakup kepemilikan perseorangan, kepemilikan skala pedesaan dan perkotaan, penyewaan dan pengaturan penggunaan lahan lainnya (Herrera 2006: 9). Sedangkan konflik merupakan situasi di mana kepentingan individu atau kolektif tertentu dalam konfrontasi. Perbedaan muncul di permukaan lantaran pihak-pihak yang melihat kepentingan mereka dirusak oleh tindakan tertentu; para pihak kemudian dapat mengembangkan sejumlah strategi untuk mencapai kepentingan mereka terpenuhi (Herrera 2006: 6). Konflik tenurial merupakan konflik kepemilikan lahan di mana konflik ini mengacu pada beberapa tipologi tenurial kehutanan yang dihasilkan 
Jurnal Pemikiran Sosiologi Volume 5 No. 1, 2018

Konflik Tenurial di Pulau Padang dan Isolasi Ekonomi Lokal Ahmad Ar Rozy, Rio Belvage, dan Oka Karyanto

penelitian kelompok sipil (Safitri dan Arizona 2011).

Adapun tipologi itu dijabarkan sebagai berikut.

Pertama, Konflik antara masyarakat adat dengan Kemenhut yang umumnya disebabkan wilayah adat telah ditetapkan sebagai kawasan hutan negara. Kedua, konflik antara masyarakat dengan Kemenhut beserta beban administrasi dari BPN. Konflik ini berupa penerbitan bukti legal atas tanah pada area yang ditetapkan dan digolongkan sebagai kawasan hutan. Ketiga, Konflik antara kelompok transmigran dan imigran dengan masyarakat setempat (lokal) di mana Kemenhut dan BPN telah terlibat dalam urusan administrasi ketetapan lahan bagi implementasi kebijakan transmigrasi. Keempat, konflik antara petani dan pekebun pendatang dengan institusi pemerintahan yang terkait urusan kehutanan dan pertanahan. Kelima, konflik antara masyarakat desa dengan Kemenhut. Hal ini terjadi karena hutan memasuki wilayah administrasi desa. Keenam, konflik antara jaringan makelar tanah dengan elit politik beserta institusi kehutanan dan pertanahan. Perihal ini muncul di permukaan karena adanya dukungan partai politik maupun ormas yang menyokong kelompok makelar tanah untuk melakukan tindakan jual beli tanah dan membantu pengesahan sertifikasi tanah tersebut. Ketujuh, konflik antara masyarakat adat dengan pemegang izin. Perihal ini dipicu adanya pembatasan akses masyarakat terhadap hutan oleh pemegang izin. Kedelapan, konflik berbagai produk izin dan pemegang izin kehutanan dengan izin pertambangan dan perkebunan. Kesembilan, Kompleksitas konflik antara berbagai produk izin beserta kepentingan kelembagaan dan jaringan pemasyarakatan.
Reaksi pendapat pakar hukum Maria Sumardjono dalam Harian Kompas bahwa kompleksitas konflik tersebut disebabkan undang-undang Pokok Agraria yang dibahas DPR dan Pakar Hukum tidak tuntas pada tahun 2009 hingga 2014. Perubahan konstitusi yang diusulkan masih sangat permukaan seperti Hak Guna Usaha (HGU) aset BUMN, upaya mengundang investor, dan okupasi masyarakat di atas HGU. Menurut pakar hukum Maria Sumardjono terjadi kesalahan persepsi mengenai hak pengelolaan (HPL) dengan kegunaan publik kemudian memasukkan "hak" dalam kategori hukum perdata merupakan keputusan legislatif yang cukup berisiko. Perihal ini memicu konstruksi hukum bahwa "HPL dapat diterbitkan di bawah HGU atau bersamaan dengan penyertaan resmi HGU". Kajian yuridis tentang Daftar Inventarisasi Masalah (DIM) versi tertanggal 17 juli 2017 yang dikeluarkan legislasi telah menuai kritik dari perspektif Maria Sumardjono menuturkan sebagai berikut :

1. Meski tujuan untuk menyelesaikan masalah okupasi tanah HGU aset BUMN itu dapat melanggar konsep " pelepasan hak " yang dibangun berdasarkan asas hak menguasai negara menurut pasal 2 UUPA dan penjelasannya. Belum jelas bagaimana konstruksi hukumnya apabila ada sebagian tanah berstatus ganda yang diberikan kepada pihak ketiga. Dari segi inventarisasi aset, bagaimana jika sebidang tanah terdapat dua macam hak atas tanah yang dipunyai oleh satu pemegang hak.

2. Dalam DIM, HGU dapat di atas tanah negara, tanah HPL, dan tanah hak milik (HM). Perihal ini dikeluar dari ketentuan 
pasal 28 UUPA yang menyebutkan bahwa HGU dapat terjadi di atas tanah negara. Secara konsepsi yuridis dalam aturan tanah negara, antara tanah HPL dan tanah HM itu berbeda dari segi sifat dan isi kewenangannya.

3. Muncul inkonsistensi pengaturan atas status tanah setelah dilepaskan dari kawasan hutan. Dalam satu ketentuan tersebut, kawasan hutan yang dilepaskan itu menjadi HPL dapat diberikan kepada pemerintah pusat, pemda, atau institusi pengelolaan tanah.

4. Ketentuan dalam DIM bahwa HPL dapat diberikan kepada masyarakat hukum adat (MHA). Tanah ulayat MHA dapat diberikan suatu hak atas tanah kepada pihak ketiga tanpa harus melalui pelepasan tanah ulayat menjadi tanah negara.

Kajian hukum di atas memberikan suatu pertimbangan bahwa pada tataran yuridis persoalan agraria dengan lokus hutan tidak pernah bertemu pada titik penyelesaian. Hal ini mampu menimbulkan konflik pada tataran akar rumput dengan berbagai macam kelompok kepentingan antar institusi. Pada aspek historisitas persoalan agraria merupakan muara dari konflik tenurial. Dengan catatan kasus penyerangan petani dari oknum aparat dan paramiliter pada tahun 2007 tepatnya di Bengkalis yang disokong oleh pihak perkebunan swasta hingga melakukan kekerasan terhadap petani perempuan (Luthfi, Razif, dan Fauzi 2008: 22).

Muara dari tidak diterimanya suatu aspirasi dan hak dapat berupa perselisihan apalagi dari dasar hukum agraria menuai keputusan yuridis bermuatan tidak memberikan jaminan sosial-ekonomi masyarakat yang selama ini menggarap lahan di area kehutanan. Dalam hal ini jika mempelajari lebih dalam terhadap konsesi areal Hutan Tanaman Industri (HTI) maka definisi ini merupakan riwayat produk ketetapan yang bersumber pada PP No.7 tahun 1990 tentang Hak Pengusahaan Hutan Tanaman Industri. Dalam peraturan tersebut menuturkan secara resmi sebagai berikut :

" Pengertian hutan tanaman industri adalah hutan tanaman yang dibangun dalam rangka meningkatkan potensi dan kualitas hutan produksi dengan menerapkan silvikultur intensif untuk memenuhi kebutuhan bahan baku industri hasil hutan. "

Ketetapan ini merupakan acuan dasar industri kehutanan dalam melakukan operasional pengolahan hutan yang dianggap produktif. Tentu saja ketetapan hukum ini juga menjadi dasar operasional industri kehutanan dan perkebunan seperti April Asia Grup yang telah berdiri sejak 1973 di bawah manajemen Sukanto Tanoto. Dengan berbagai produk dan jaringannya Sukanto mampu memberikan yayasan beasiswa bagi kelas menengah mahasiswa dan sektor pendidikan yang dianggap bentuk pemberdayaan sosial (CSR). Sukanto dengan infrastruktur modalnya telah menciptakan berbagai institusi unit ekonomi yang membagi pada jenis produksi kehutanan dan perkebunan (Laman online http://aprilasia.com. Diakses 26 Januari 2018). Pada hubungan ini areal HTI merupakan lahan kawasan hutan yang menerapkan budidaya kehutanan 
(silvikultur) untuk memenuhi produk kehutanan baik kayu maupun non kayu.

Pemenuhan pasar produk kehutanan yang memakan waktu sepanjang empat dekade atau 40 tahun cukup menimbulkan dampak seperti kayu yang dipanen dari hutan alam semakin masif, sehingga areal hutan alam mengalami alih fungsi untuk hutan produksi. Maka dari itu, dampak dari operasional ini menimbulkan efek yang cukup berantai dari mekanisme kehidupan sosial-ekonomi. Salah satu institusi produk April Asia Grup yang menuai reaksi sosial maupun institusi pemerintahan pusat dalam hal ini adalah Kementerian Lingkungan Hidup maupun Kehutanan adalah PT. Riau Andalan Pulp and Paper atau disingkat PT RAPP.

Rumusan di atas berdasarkan pernyataan 22 Oktober 2017 lalu Menteri Lingkungan Hidup dan Kehutanan Siti Nurbaya Bakar menyimpulkan PT RAPP yang tidak patuh pada regulasi pemerintahan nasional. Pasca rencana kerja eksekusi yang dinyatakan ilegal. PT RAPP tidak diperkenankan menanam ulang pada areal konsesinya. Pembatalan pengesahan rencana eksekusi tersebut menjadi polemik asosiatif antara institusi pemerintahan, PT RAPP, dan kelompok masyarakat sipil setempat. Dari institusi pemerintah pusat pihak PT RAPP mendapatkan sanksi karena tidak ingin melakukan perubahan terhadap rencana kerja yang ada. Sedangkan pada ranah publik, PT RAPP mengaku “ izinnya selama ini dicabut “. Pihak RAPP mengajak koalisi pelaku industri kehutanan untuk bersamasama mengeluhkan aturan restorasi gambut.

Dari catatan Kementerian Lingkungan Hidup, bahwa terdapat 99 perusahaan yang area konsesinya masuk lahan gambut, jika tidak direstorasi maka tragedi kebakaran dan hujan asap akan berulang di tempat yang terutama di Provinsi Riau. Pihak Kementerian menganggap pelaku industri tidak mau melakukan tata ulang rencana kerja untuk kepentingan ekosistem gambut dikarenakan khawatir kehilangan konsesi lahan gambut apalagi yang baru digunakan 200an hektar dari 338 hektare. Sedangkan pihak pelaku industri RAPP menganggap akan kehilangan $30 \%$ dari konsesi mereka (Thorburn and Kull 2015: 37 ).

Runtutan konfliktual antara RAPP dengan Kementerian Lingkungan Hidup tersebut masih pada tataran yuridis namun secara sosiologis masih sangat elitis atau terjadi pada kelompok pengambil kebijakan. Sedangkan pada ranah masyarakat terjadi konflik realistis dengan perubahan ekosistem alam sangat mengkhawatirkan terutama di Pulau Padang. Catatan studi mediasi menuturkan pada periode berikut terjadi kondisi konflik :

1. Pada periode $1997-2003$ telah terjadi 359 kasus konflik sehingga tercatat $39 \%$ di areal konservasi termasuk hutan lindung dan taman nasional. Sedangkan $27 \%$ di areal HPH (Tim Mediasi 2011). Efek dari situasi konflik berkepanjangan ini menimbulkan pihak masyarakat setempat kehilangan haknya sehingga menjadi korban karena dianggap melawan hukum. Perihal ini dikarenakan pihak perusahaan telah memenangkan pengadilan secara yuridis sehingga jika masyarakat melakukan protes dianggap melawan keputusan hukum. Meskipun terjadi konsesi HTI sehingga kemenangan PT RAPP ditinjau kembali. Akan tetapi dalam proses penegakan hukum hingga bulan November 2010, pihak Dirjen 
Jurnal Pemikiran Sosiologi Volume 5 No. 1, 2018

Konflik Tenurial di Pulau Padang dan Isolasi Ekonomi Lokal Ahmad Ar Rozy, Rio Belvage, dan Oka Karyanto

Kehutanan melakukan keputusan berupa dukungan bahwa konsesi itu legal dan terus berlanjut. Kekuatan hukum positif telah intervensi sehingga via-a-vis dengan hak kelompok masyarakat setempat. Hal ini mengindikasikan legalitas birokrasi tidak solutif dalam menyelesaikan konflik antara warga setempat dengan perusahaan PT. RAPP.

2. Konsorsium Pembangunan Agraria (KPA) tahun 2011 mencatat 163 konflik agraria meningkat $35 \%$ dibandingkan tahun sebelumnya 106 konflik. 33 konflik berada di daerah kehutanan. RAPP mendapatkan perluasan HTI 235.140 ha menjadi 350.167 ha. Dari jumlah itu 41.205 berada di Pulau Padang, provinsi Riau dan mendapat perlawanan warga. HTI terbesar dan paling kontroversial konsesi di Kepulauan Meranti adalah PT RAPP di Pulau Padang. Konsesi 41 205 hektare mencakup hampir 40\% total Pulau Padang berbatasan dengan 14 desa di pulau ini.

Aktivis lokal mengklaim bahwa kawasan konsesi tersebut meliputi tanah leluhur penduduk desa, dan itu pembersihan lahan dan drainase akan sangat membahayakan lingkungan pulau itu (Thorburn and Kull 2015: 48). Dua pertiga wilayah konsesi (27.775 hektar) milik PT RAPP telah tercatat untuk ditanami akasia, dan sisanya disisihkan untuk ditanami jenis kayu, dan 'tanaman sumber mata pencaharian'. Selama tahun 2009 hingga 2010, PT RAPP mendapatkan jaminan surat dari sebelas kepala desa dari desa di pulau itu yang menyetujui konsesi operasional. Hal ini karena melakukan klaim bahwa perusahaan akan memberikan ratusan pekerjaan baru terutama membuat program sosial dan pendidikan, dengan dukungan untuk usaha pertanian serta usaha kecil. Tiga desa yang terletak di Jalan selatan pulau itu menolak konsesi itu sama sekali, dan antara tahun 2010 dan 2012, delapan Dewan Desa dari sebelas 'konsesi pro' desa juga mengeluarkan surat-surat yang menolak konsesi tersebut (Thorburn and Kull 2015: 65).

Pada tanggal 30 Desember 2009 masyarakat dari berbagai desa di Kabupaten Kepulauan Meranti khususnya desa-desa dari Pulau Padang antara lain Tanjung Padang, Selat Akar, Kudap, Dedap, Mengkopot, Mengkirau, Bagan Melibur, Pelantai, dan beberapa desa di luar Pulau Padang seperti Semukut, Renak Dungun, Sungai Tohor, dan desadesa lain yang berjumlah 1000 an orang mendatangi Kantor Bupati Kepulauan Meranti (di Selat Panjang) yang saat itu di Jabat oleh Bupati Syamsuar masyarakat dan Kepala Desa-kepala desa yang memimpin aksi tersebut dengan menolak rencana operasional PT. RAPP di Pulau Padang. Bupati Syamsuar yang saat itu menjabat, telah mendukung apa yang dilakukan Masyarakat untuk menolak kehadiran PT. RAPP beroperasi di Pulau Padang (Tim Mediasi 2011: 25).

Kronologi perluasan area PT. RAPP oleh Dinas Kehutanan Provinsi Riau, Januari 2010, yang berisikan 12 item cacat administrasi dalam proses dikeluarkannya SK Menhut No. 327 tahun 2009 dan merekomendasikan untuk di tinjau ulang berjumlah delapan petisi atau tanda tangan penolakan masyarakat Pulau Padang terhadap PT. RAPP di Pulau Padang berbaur menjadi satu baik dari tokoh masyarakat, tokoh agama, RT, RW, Kepala Dusun, Kepala Desa, perangkat desa, dan BPD. Berkas- 
Jurnal Pemikiran Sosiologi Volume 5 No. 1, 2018

Konflik Tenurial di Pulau Padang dan Isolasi Ekonomi Lokal

Ahmad Ar Rozy, Rio Belvage, dan Oka Karyanto

berkas tersebut diterima langsung oleh Kuswanto

dari Komite Penerima Laporan Pengaduan

Masyarakat (Tim Mediasi 2011: 24).

\begin{tabular}{|c|c|c|}
\hline Permasalahan & Peristiwa & Mediasi Penyelesaian \\
\hline 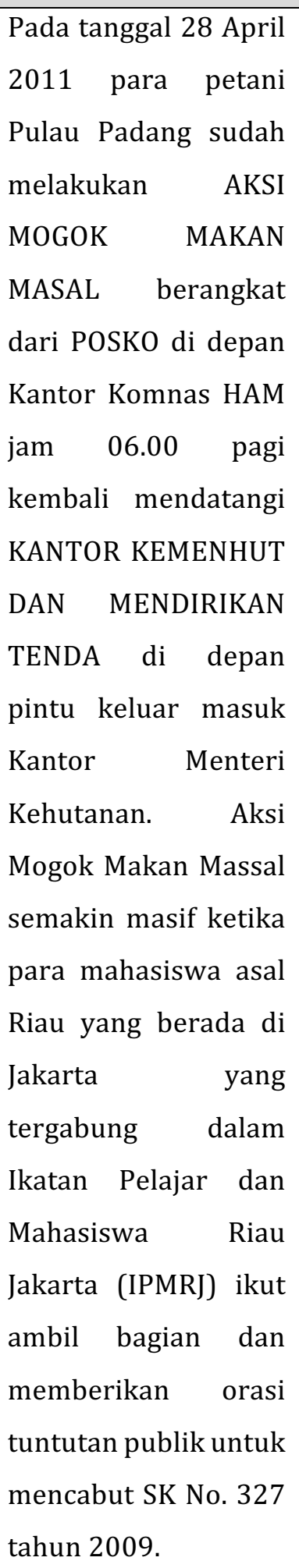 & $\begin{array}{l}\text { Tujuh orang perwakilan Petani Pulau } \\
\text { padang diperkenankan untuk masuk } \\
\text { dan menemui Menteri Kehutanan } \\
\text { Zulkifli Hasan. Pertemuan para } \\
\text { petani dengan Menteri Kehutanan } \\
\text { Zulkifli Hasan yang didampingi oleh } \\
\text { Hadi Daryanto (Setjen Kemenhut) } \\
\text { Iman Santoso (Dirjen), Bedjo Santoso } \\
\text { (Direktur Bina Kehutanan) dan } \\
\text { beberapa pejabat lain dilingkungan } \\
\text { Kementerian Kehutanan, tidak } \\
\text { seideal harapan tetapi justru para } \\
\text { petani diprovokasi dan ditantang } \\
\text { oleh Menhut. }\end{array}$ & $\begin{array}{l}\text { Pertama, Menhut menyangsikan } \\
\text { bahkan tidak percaya bahwa } \\
\text { para petani yang sudah berhari- } \\
\text { hari melakukan aksi penolakan } \\
\text { Operasional PT. RAPP di Pulau } \\
\text { Padang di Jakarta dan menuntut } \\
\text { Pencabutan SK Menhut No. } 327 \\
\text { tahun } 2009 \text { bukan asli warga } \\
\text { Pulau Padang. Kedua, Menhut } \\
\text { menyatakan bahwa -pulau } \\
\text { Padang tidak berpenghuni dan } \\
\text { ketiga, mengancam dengan } \\
\text { pernyataannya saudara-saudara } \\
\text { mau demo silakan, satu hari, dua } \\
\text { hari, tiga hari, sebulan, setahun } \\
\text { silakan, tapi jangan ganggu kami, } \\
\text { kalau ganggu kami saya lawan } \\
\text { (Laporan TIM MEDIASI PULAU } \\
\text { PADANG SK.736/Menhut- } \\
\text { II/2011 tanggal } 27 \text { Desember } \\
2011 \text { ) }\end{array}$ \\
\hline
\end{tabular}




\begin{tabular}{|c|c|c|}
\hline $\begin{array}{l}\text { Pada tanggal } 30 \text { Mei } \\
2011 \text { warga pulau } \\
\text { padang dari berbagai } \\
\text { desa melakukan aksi } \\
\text { PENGHENTIAN } \\
\text { OPERASIONAL PT. } \\
\text { RAPP secara paksa di } \\
\text { lokasi operasional } \\
\text { Desa Tanjung Padang } \\
\text { tepatnya di Sungai } \\
\text { Hiu, tepat di jalan } \\
\text { koridor. Tanggal } 30 \\
\text { MEI 2011 }(23.00 \\
\text { WIB.) }\end{array}$ & $\begin{array}{l}\text { Pasca massa aksi pulang di Kampung } \\
\text { halaman masing-masing, } \\
\text { menggunakan } 6 \text { kapal pompong, } \\
\text { diketahui dari berbagai media lokal } \\
\text { bahwa di areal Jalan Koridor PT. } \\
\text { RAPP Sg. Hiu Desa Tanjung Padang, } \\
\text { terjadi pembakaran } 2 \text { alat berat dan } \\
2 \text { kamp PT. RAPP. Akibat peristiwa } \\
\text { tersebut warga Desa Tanjung Padang } \\
\text { diburu pihak aparat meskipun tanpa } \\
\text { bukti dan alasan yang jelas. Beberapa } \\
\text { orang warga desa Tanjung Padang di } \\
\text { tangkap, salah satunya Zainal (warga } \\
\text { dusun tanjung padang) rumahnya } \\
\text { dikepung pada pagi hari oleh lebih } \\
\text { kurang 14 aparat kepolisian } \\
\text { bersenjata lengkap dan kemudian } \\
\text { dibawa ke Mapolresta Bengkalis } \\
\text { untuk dimintai keterangan. Namun } \\
\text { kemudian dilepaskan. Hingga tanggal } \\
7 \text { Januari } 2012 \text { masih ada } 24 \text { nama } \\
\text { warga Desa Tanjung Padang, yang } \\
\text { terus di buru oleh pihak aparat } \\
\text { kepolisian tanpa alasan yang jelas. }\end{array}$ & Tidak ada penyelesaian. \\
\hline
\end{tabular}

Tabel Deskripsi Mediasi Permasalahan (Konflik) di Pulau Padang

(Sumber data: primer)

Dari studi mediasi penyelesaian di atas menunjukkan bahwa konflik perebutan areal kehutanan dan perkebunan telah menjadi laten. Konflik muncul di permukaan karena status kuasa hukum, hak pengelolaan dan pemanfaatan jenis hutan dan perkebunan, kemudian disertai pemanfaatan redistribusi. Kondisi produk hukum yang carut-marut mengakibatkan status hukum tidak mempunyai peran yang dapat diterapkan khususnya tentang pembagian kerja masyarakat dan koridor pelestarian lingkungan alam baik tentang lahan gambut maupun aspek-aspek yang mendukung kelestarian ekosistem alam. 


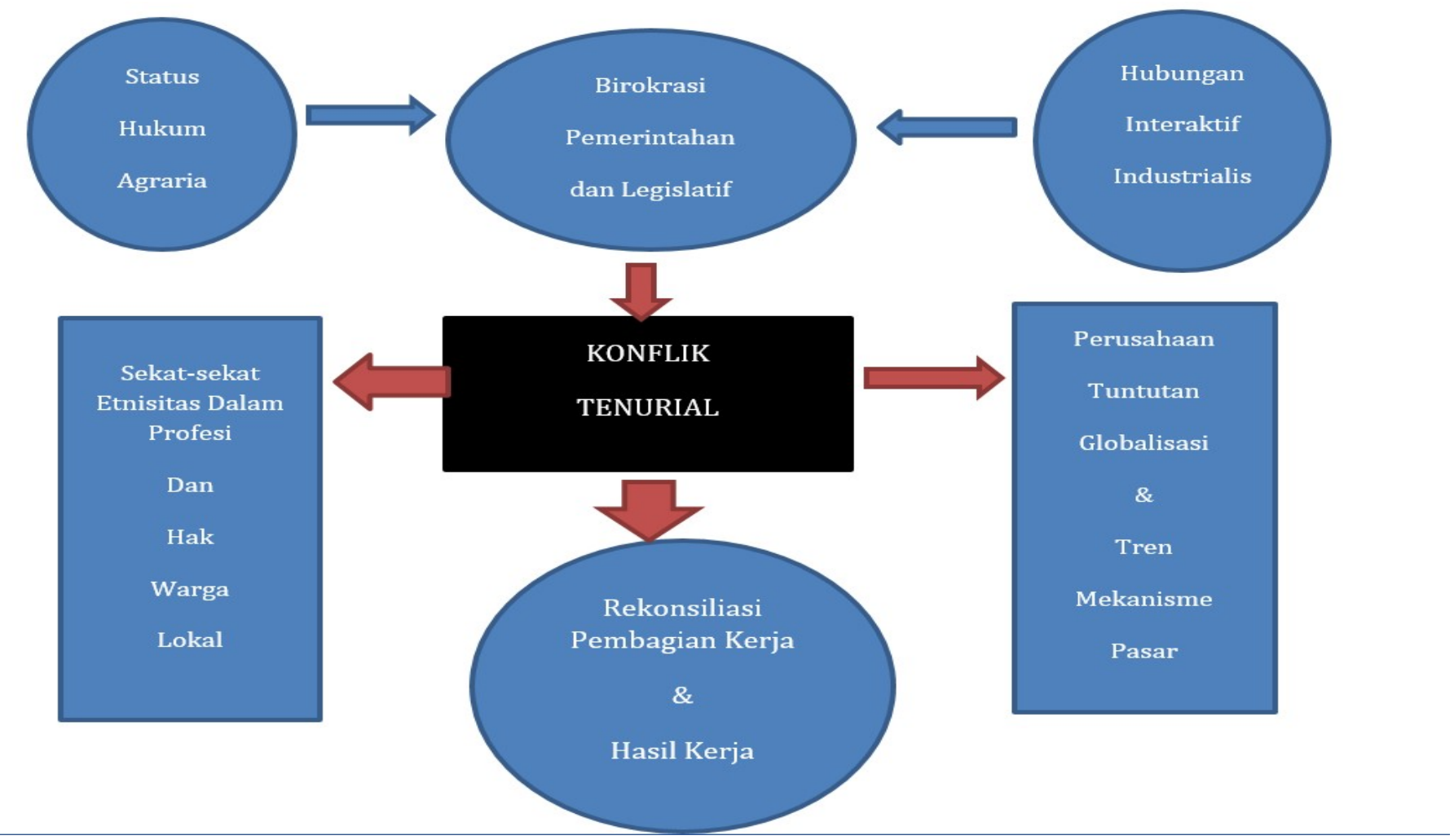

Gambar Skema Komplesitas Konflik Tenurial (Sumber: data primer)

Kondisi legal dari peraturan undang-undang D. Muatan Konflik dan Persepsi Praktik
Kesejahteraan Sosial kehutanan sebagaimana termaktub dalam UU No. 5 Tahun 1967 maupun UU No. 41 Tahun 1999 tentang Kehutanan sama-sama mengakui keberadaan hak ulayat tetapi masih parsial, kemudian diteliti dari pasal 2 UU yang hanya mampu meresmikan ' hutan Negara ' dan ' hutan Milik ' (Nugraha 2005: 397). Konstruksi hukum ini masih memikirkan tiga negosiasi antara lain dari perspektif konservasi, industri, dan hak ulayat. Akan tetapi yang perlu digarisbawahi di sini sebetulnya seperti apa tiga karakteristik gerak dari negosiasi tersebut. Tidak ada yang menjamin ketiga aspirasi tersebut mampu berjalan secara seimbang.

Proposisi sejarah ekonomi kepulauan yang dibangun Howard Dick, Vincent Houben, Thomas Lindblad, dan Thee Kian Wie. Masyarakat prakapital sebelum abad ke-19 menempatkan modernisasi dua abad terakhir ketika terjadi perubahan konfigurasi lokal dan global yang diawali tahun 1900. Akan tetapi transisi sejarah ekonomi Indonesia menyatakan perbedaan yang tidak linear. Yakni kondisi modernisasi Indonesia yang dibangun kebijakan Orde Baru dalam lingkup industri tidak memenuhi aspek cara berpikir fungsional dan inovatif namun hanya penyerapan tenaga kerja di bidang pengolahan dan perakitan (Dick, Houben, Lindblad, Kian Wie 2002). Pada kebijakan Orde Baru, birokrasi merupakan kontrol publik dengan regulasi ketat sehingga tidak menjadi pelayanan 
Jurnal Pemikiran Sosiologi Volume 5 No. 1, 2018

Konflik Tenurial di Pulau Padang dan Isolasi Ekonomi Lokal Ahmad Ar Rozy, Rio Belvage, dan Oka Karyanto

publik bagi tatanan perekonomian rakyat (Purwanto 2008: 22). Hal ini menjadi bumerang dan secara tidak langsung melakukan isolasi potensi kekuatan ekonomi lokal di mana ekonomi lokal sesungguhnya sangat memahami bagaimana melakukan produksi ekonomi yang ramah dengan lingkungan alam.

Akibatnya telah banyak masyarakat tertinggal pada konstruksi modernisasi tetapi penggunaan usaha mandirinya masih pada tahap era kolonial (Dick et al 2002). Howard Dick menuturkan lima tahapan menuju keseimbangan orientasi ekonomi berdasarkan periodisasi perkembangan sejarah:

1. Tingkat spesialisasi ekonomi. Peluang pasar dipengaruhi kepentingan relatif produksi pertanian untuk ekspor, produksi manufaktur dan pembagian kerja. Pasca reformasi semestinya merupakan momentum melakukan penataan pembagian dan hasil kerja namun momentum ini tidak mendapatkan konsensus antara kelompok pemerintahan, kelompok sipil dan kelompok pengusaha.

2. Rentang dan diferensiasi jaringan komersial. Sejauh mana jaringan perdagangan atau jaringan pasar yang dilokalkan atau dihubungkan dalam akses ekonomi global? Seberapa canggih fasilitas transportasi di tingkat teknologi yang berlaku ( Dick et al 2002: 44 ).

3. Tingkat monetisasi.

4. Tingkat urbanisasi.

5. Sifat regulasi ekonomi.
Berapa keseimbangan antara perlindungan dan fasilitasi kegiatan ekonomi versus ekstraksi oleh sentralitas kebijakan publik? Persoalan yang mengemuka ialah masih terdapat subsistensi ekonomi yang kalah bersaing secara desain produk dan prasyarat kualitas hasil kerja pada ranah jaringan ekonomi kepulauan (Belvage, 2017). Pembangunan industri dan kelembagaan pemerintah lokal tidak mengajarkan pertumbuhan penduduk dalam mengelola keseimbangan alam dan kemajuan teknologi tetapi hanya merangsang pertumbuhan populasi yang sangat mudah dimanfaatkan sebagai tempat pasar (market-place). Sebaliknya temuan etnografi menggambarkan realitas yang mampu mengancam hajat masyarakat setempat beserta lahan garapan masyarakat yang pada waktu itu berjumlah sekitar 33 ribu jiwa, tetapi juga merusak ekosistem alam. Inisiatif tentang kapitalisasi industri pengolahan kayu menimbulkan dorongan untuk meningkatkan pendapatan negara dari sumber estraktif. Hal ini memicu elit Negara untuk mengubah peraturan kawasan hutan di Pulau Padang dari HPT menjadi Hutan Tanaman Industri (Belvage, 2017 ).

Hasil etnografi mencatat masyarakat Pulau Padang menyandarkan hidup dari bertanam karet dan sagu. Tanaman sagu lazim digunakan sebagai tabungan oleh masyarakat karena batang pohon dapat dipotong setiap saat - sementara untuk tumbuh sampai menunggu panen sendiri butuh waktu bertahun-tahun, maka kebun karet lebih menjadi pilihan untuk mencukupi kebutuhan sehari-hari karena getah dapat diperoleh setiap hari. Catatan pengakuan warga setempat di tahun 2016, harga karet di desa jatuh sampai Rp. 3.000/kg. Ketika harga demikian rendah, orang lebih memilih 
Jurnal Pemikiran Sosiologi Volume 5 No. 1, 2018

Konflik Tenurial di Pulau Padang dan Isolasi Ekonomi Lokal Ahmad Ar Rozy, Rio Belvage, dan Oka Karyanto

meninggalkan kebun dan merantau untuk mendapatkan uang ringgit di Malaysia. Salah seorang tokeh bernama Ahmad Hambari mempunyai keputusan bisnis yang terbilang 'berani'. Ia dianggap memotong rantai distribusi karet tanpa melalui tokeh besar di Selat Panjang, tetapi langsung mengantarnya sendiri ke Pekanbaru (Belvage 2017). Dengan begitu, ia tetap berani membeli getah karet petani dengan harga yang lebih tinggi.

Rio Belvage sebagai peneliti antropologi tertarik untuk menghitung persamaan upah mbalak dengan nilai emas saat ini. Jika waktu itu harga 1 gram emas 25 ribu, sedang upah dari mbalak 500 ribu, maka sama halnya ia mendapatkan 20 gram emas. Dalam hitungan situasi tersebut, 20 gram emas setara dengan sekitar 10 juta rupiah lebih. Jumlah yang sangat besar jika dibandingkan dengan perolehan karet di desa. Belvage kemudian menghitung jumlah penghasilan rata-rata kelas menengah yang tinggal di Desa Sungai Anak Kamal berkisar antara 3 juta rupiah. Artinya jika diperbandingkan, pendapatan hasil mbalak kayu itu setara dengan pendapatan pemilik kebun karet yang luasnya berhektar-hektar. Sedangkan, di Sungai Anak Kamal sendiri yang memiliki kebun seluas itu saat ini hanya dapat dihitung jari. Salah-satunya, karena seiring waktu luas area kepemilikan lahan masyarakat terus diwariskan turun-temurun, sementara di sisi lain akses untuk pembukaan lahan baru terhenti sejak tahun 2010an ( Belvage 2017).

Ketika Negara memperkenalkan istilah Hutan Produksi Terbatas (HPT) - sehingga ketersediaan lahan yang semula luas pun semakin lama semakin menyempit seiring bertambahnya tingkat kepadatan penduduk dari waktu ke waktu. Kebun karet semakin waktu kian sempit karena terbagibagi, masih ditambah lagi dengan harga getah karet yang dari dulu sampai sekarang tidak jauh berbeda kemudian kondisi penentuan harga naik-turun yang tidak pasti (Belvage 2017).

Di tahun 80an, harga satu kilo getah karet berkisar antara 700 sampai 800 rupiah.Di tahun 2014-2016 harga getah karet sempat jatuh sampai 3500$4000 / \mathrm{kg}$, harga yang sudah tentu membuat seluruh warga desa mengalami paceklik (Belvage 2017: 6). Dari harga sebelumnya yang sempat melambung 18.000-20.000/kg sekitar tahun 2009-2010, tetapi itu hanya bertahan beberapa bulan saja ( Belvage 2017 : 6). Kondisi harga getah yang lebih kerap jatuh ketimbang naik itulah yang mendorong warga setempat memutuskan untuk mencari kerja ke Malaysia. Di balik ekonomi para perantau di sebuah desa di Pulau Padang ini sebetulnya tidak lain dilatarbelakangi rendahnya pendapatan yang dihasilkan di desa. Rio Belvage masih mencatat percakapannya dengan seorang warga di atas perahu ketika menunggu air pasang setelah perjalanan menjual karet dari Selat Panjang.

"Kalau hasil dari karet cukup, ya lebih memilih kerja di kampung saja mas."

Hal ini menyiratkan bahwa pabrik-pabrik dan pengiriman produk pengolahan manufaktur dalam negeri (dalam pulau) tidak mampu memikirkan keberadaan ekosistem dan mata rantai ekonomi lokal yang sebetulnya juga menunjang keberlanjutan produksi manufaktur. Konversi dan upaya drainase yang diubah menjadi kawasan HTI penghasil bubur kayu kertas (pulp) dan perkebunan kelapa sawit menjadi kendala tersendiri bagi 
keberlanjutan ekosistem alam. Tanggung jawab dan konsensus nasional tentang misi kelestarian ekologi dan mata rantai ekonomi lokal dipertanyakan dengan drainase yaitu kelestarian produktivitas, tingkat emisi gas rumah kaca, dan risiko banjir (Karyanto 2008: 205). Sebaliknya keberadaan lahan gambut yang ditetapkan sebagai drainase merupakan potensi bahan bakar pada skala luas sehingga secara periodik mengakibatkan dampak kebakaran (Karyanto 2008: 205). Upaya konversi yang memberikan dampak bencana juga menjadi peringatan (warning) bagi munculnya konflik bahkan dalam skala nasional sehingga menimbulkan intervensi antara warga setempat, birokrasi pemerintahan lokal, pimpinan pabrik, kelompok jasa distribusi, kelompok pemerhati alam dan pemerintahan pusat. Dalam hal ini pepatah Melayu mengatakan "ibarat telur sesangkak, pecah sebiji, pecah sетиа" atau kekhilafan tindakan seseorang yang berpengaruh menyebabkan orang lain menerima akibatnya.

Masyarakat lokal membutuhkan rangsangan dan dorongan kolektif berupa integritas dan seperti apa gambaran kebutuhan untuk memenuhi kesejahteraan masyarakat dan ekosistem setempat. Bradshaw (1972) memaparkan sintesa untuk menuju kesejahteraan sosial dibutuhkan identifikasi "kebutuhan yang dirasakan" dan "kebutuhan yang diungkapkan" (Spicker 1988: 11). Kebutuhan yang dirasakan adalah materialitas pokok yang perlu dimiliki setiap waktu, sedangkan kebutuhan yang diungkapkan adalah potensi kekuatan berupa keinginan yang perlu disalurkan sesuai dengan koridor batasan ruang privat kepada ruang publik. Batasan konstruksi pengetahuan ini dibentuk untuk memenuhi kebutuhan aktualisasi diri berdasarkan kemampuan dan fungsionalisasi individu di ruang publik atau ranah industri.

Pokok-pokok kesejahteraan sosial sebenarnya mampu diadaptasi secara sederhana dengan administrasi terapan (applied public administration) seperti program kesejahteraan abdi negara (Keban, 2004). Pemerintahan lokal yang berperan sebagai agensi resmi sepatutnya mengakomodasi warga yang mampu bertahan dengan "ekonomi kaki lima" dengan program-program yang sesuai kemampuan tiap-tiap usia yaitu asuransi kesehatan, fasilitasi rangsangan modal keuangan, dan asuransi pendidikan. Pelaksanaan program ini sesuai dengan kesepakatan antara administrasi desa dengan warga.

Asuransi pembiayaan kesehatan dapat dikelola dengan Rumah Sakit Umum atau Pusat Kesehatan Masyarakat. Sedangkan asuransi pendidikan dapat dipegang oleh sekolah tinggi maupun universitas. Dalam hal ini jika asuransi pendidikan dikelola oleh universitas dengan tertata dan tepat sasaran maka universitas dapat membentuk komunitas sosial yang mampu mengubah sistem dengan manajemen inovatif. Apabila peran pemerintah sebagai agensi resmi tidak mampu beroperasi dengan baik maka peran tersebut diambil oleh komunitas kelompok sipil (LSM). Dari keluaran (output) program tersebut diharapkan mampu melahirkan tenaga mekanik dan tenaga ahli yang mampu mengembangkan potensi lokal dan memberikan dampak produksi yang berkualitas dengan cara-cara setempat, sehingga keluar dari isolasi rezim lokal. 
Jurnal Pemikiran Sosiologi Volume 5 No. 1, 2018

Konflik Tenurial di Pulau Padang dan Isolasi Ekonomi Lokal

Ahmad Ar Rozy, Rio Belvage, dan Oka Karyanto

\section{E. Rekonsiliasi Pembagian Kerja Menuju Ekonomi Kolektif}

Rekonsiliasi pembagian kerja merupakan penataan kembali dan langkah inovasi pembagian kerja sesuai kebutuhan industri dan kebudayaan. Kemudian jika ditanya, siapa yang berhak melakukan pembagian kerja beserta hasilnya? Tentu semua kembali kepada masyarakat sendiri (mutual self-collective group) dengan peran pemerintahan setempat. Pada tahap ini kembali kepada komitmen kelompok pengusaha menengah dan kelompok politik lokal. Apakah mempunyai komitmen melakukan rekonsiliasi pembagian kerja.

Rekonsiliasi dapat dibuat model dengan cara berpikir mekanis tetapi kebutuhan yang diharapkan tidak semata-mata suatu "program mekanisasi." Akan tetapi proses pengenalan individu satu dengan individu lain dengan langkah rekognisi. Langkah ini merupakan dasar dari rekonsiliasi budaya bahwa apakah masyarakat mampu mengenal kekuatan solidaritas dengan baik. Rekognisi bukan hanya sekadar mengenali dengan latar belakang etnis dan profesi tetapi kemampuan kolektif di mana mampu menghargai (respected) hasil kerja bahkan menghargai diri sendiri (self-esteem). Beserta capaian-capaian (achievements) yang selama ini memberikan dampak konstruktif bagi masyarakat setempat.

Rekognisi memiliki bentuk spirit saling memiliki (sense of belonging), pemenuhan hak-hak individu yang normal (rights), dan kekuatan soliditas masyarakat dalam mengatasi masalah umum seperti ekonomi (Honneth, 1995). Rekognisi merupakan perjumpaan subyektif-subyektif masyarakat berkenalan dalam suatu ruang dengan menetapkan moralitas yang patut diberlakukan pada kebutuhan situasi setempat. Hal ini dilakukan supaya meraih tujuan kesejahteraan bersama.

Model rekognisi berbasis pada daya afektif dan konseptualisasi kognitif yang berasal dari keluargakeluarga bernasib pada lingkungan yang sama sehingga dapat muncul kesinambungan masyarakat sipil yang sadar akan pentingnya aturan bersama untuk menghendaki tujuan kesejahteraan bersama. Berbagi perasaan tentang ungkapan afektif merupakan langkah pra-kondisi keikutsertaan untuk mengatasi problem yang sedang berjalan dengan cara saling mengakui (mutual recognition). Rekognisi dapat mengenali suatu kapasitas individu di mana tergantung kemauan pengkondisian dari keberadaan lingkungan. Sedangkan ekonomi sesungguhnya merupakan konsepsi cara berpikir pertukaran komoditi supaya laku untuk diperjualbelikan dengan mengambil moralitas umum yaitu penguatan pada nilai tambah (value added) dari jarak, psikologis, dan kemasan (pada konstruksi pemasaran modern).

Maka dari itu, cara berpikir ekonomi berorientasi pada nilai tambah di mana berasal dari konstruksi pengetahuan yang diterapkan pada tindakan rasional. Sedangkan cara berpikir konservasi sebetulnya pasifikasi dari kemauan masyarakat setempat yang dipengaruhi reaksi bencana alam dan opini publik dari dampak bencana alam tersebut. Kedua cara berpikir tersebut perlu menjadi pertimbangan para pengambil keputusan pada tingkat masyarakat. Dengan dimulai dari komunitas pendidikan konservasi dan pengembangan ekonomi yang berorientasi pada nilai tambah. Moralitas yang diambil dari kesempatan ini adalah konsepsi manajemen berbasis partisipasi. Keputusan 
Jurnal Pemikiran Sosiologi Volume 5 No. 1, 2018

Konflik Tenurial di Pulau Padang dan Isolasi Ekonomi Lokal Ahmad Ar Rozy, Rio Belvage, dan Oka Karyanto

partisipasi merupakan tindakan yang perlu diapresiasi dan disadari secara bersama dengan menentukan tujuan jangka pendek dan sasaran jangka panjang (goal attainment).

\section{F. Kesimpulan}

Eskalasi dan tipologi konflik tenurial di atas menunjukkan pertikaian sosial ini menjadi laten. Status kuasa hukum, hak pengelolaan dan pemanfaatan jenis hutan dan perkebunan, kemudian disertai pemanfaatan redistribusi merupakan muatan konflik yang perlu segera untuk diselesaikan pada ranah sosial. Kondisi produk hukum yang tidak jelas (the indistincly of law) mengakibatkan status hukum tidak mempunyai peran yang dapat diterapkan khususnya tentang pembagian kerja masyarakat dan koridor pelestarian lingkungan alam.

Konstruksi hukum ini masih memikirkan tiga negosiasi antara lain dari perspektif konservasi, industri, dan hak ulayat. Akan tetapi yang perlu digarisbawahi di sini sebetulnya seperti apa tiga karakteristik gerak dari negosiasi tersebut. Tidak ada yang menjamin ketiga aspirasi tersebut mampu berjalan secara seimbang. Maka dari sini diperlukan konsensus baru (the new consensus) dengan menghasilkan fakta-fakta yang terjadi pada realitas empiris.

Akhir dari pembahasan ini merupakan usulan bentuk kerja kolektif seperti gotong-royong di mana mampu mengangkat harga diri (self-esteem) kebangsaan secara lokalitas. Pengetahuan lokal menjadi basis untuk meningkatkan basis ekonomi dan upaya konservasi. Hanya perlu dimulai dengan proses perkenalan (rekognisi) antar individu secara berkesinambungan. Dengan mengenali reputasi sejarah, pencapaian berdampak konstruktif (achievements), kemampuan baru dan keahlian (expertise) maka perkara konflik diharapkan mulai berkurang.

Tidak hanya itu, komunitas pendidikan memegang peran penting dalam pengembangan masyarakat khususnya dalam pelatihan yang menajamkan pada cara berpikir kreatif dan bertanggungjawab. Dengan demikian menjadi modal individu untuk menghadapi persaingan atau jenis-jenis usaha ekonomi kepulauan. Gerak komunitas pendidikan dapat dibentuk berdasarkan usia dan angkatan kerja (peer-group) di mana perlu memiliki mentor yang ahli dalam bidang edukasi dan ilmu teknik dasar. Hal ini semua berdasarkan pengembangan masyarakat dari bawah. Pengambilan moralitas berdasarkan keputusan dan kesepakatan sosial merupakan rekonsiliasi konflik yang berorientasi pada kreativitas dalam melestarikan alam dan aset tidak bergerak seperti tanah, pelabuhan, peninggalan bangunan. Dewasa ini, komunitas pendidikan berbasis konservasi mulai mengembangkan holtikultura, hidroponik, Indonesia Berkebun, teknologi daur-ulang (recycle), warung vegetarian, dan arsitek alternatif (kerangka bambu).

Pada aspek institusi pemerintahan lokal yang diamanati secara resmi melalui undang-undang yang berlaku maka nilai-nilai pelayanan publik menjadi sangat penting dalam prasyarat kemajuan daerah. Nilai-nilai pelayanan publik mencakup integritas, kecepatan pelayanan, simpati, tidak sektoral dan rasa berkewajiban memajukan taraf hidup masyarakat (Ratminto dan Winarsih, 2006). Hal ini secara mekanis dapat menimbulkan resiprositas positif bagi abdi negara sehingga 
masyarakat memberikan penilaian positif dan kepercayaan atas tindakan pelayanan dengan timbal balik seperti guru dengan murid atau dokter dengan pasien. Pada langkah solidaritas masyarakat adalah bentuk stimulan dari berbagai kelompok yang mencakup keterlibatan umum sebagai warganegara (civic engangement) seperti asosiasi dan jaringan yang memiliki tujuan kesejahteraan bersama dengan mekanisme kerja sama dan sinergi antar kelompok.

\section{Daftar Pustaka}

Belvage, Rio. 2017. "Laporan Awal Pulau Padang." Kelompok Kerja Gambut UNDP-BRG- Fak. Kehutanan UGM. 2 Februari.

Damsar, Azis. Indrayani. 2009. Pengantar Sosiologi Ekonomi. Jakarta: Kencana Group.

Daryono, Herman. 2009. "Potensi, Permasalahan dan Kebijakan Yang Diperlukan Dalam Pengelolaan Hutan dan Lahan Rawa Gambut Secara Lestari“. Jurnal Analisis Kebijakan Kehutanan. Vol. 6. No. 2 : 71-101.

Dick, Howard. Houben, Vincent. Lindblad, Kian Wie, Thee. 2002. The Emergence Economy of a National Economy : An Economic History 1800-2000. Honolulu: The University of Hawaii Press.

Hamidi, Hanibal. 2014. Perdesaan Sehat. Jakarta: Merdesa Institute.

Herrera, Andriana. and Maria Da Passano. 2006. Land Tenure Alternative Conflict Management. Rome: FAO-United Nation.

Honneth, Axel. 1995. The Struggle for Recognition : The Moral Grammar of Social Conflicts. Translated Joel Anderson. Cambridge, MA: The MIT Press.

Hoopes, James. 1979. Oral History. Chapel Hill: The University of North Carolina Press.
Karyanto, Oka. 2008. "Drainase Hutan Rawa Gambut: Berkah atau Bencana ? Kilas Balik Atau Perspektif Ke Depan“. Darurat Hutan Indonesia. Disunting oleh Nugroho Agung. Tangerang : Wana Aksara.

Keban, Yeremias. 2004. "Pokok-Pokok Pikiran Perbaikan Sistem Manajemen PNS di Indonesia." Jurnal Kebijakan dan Administrasi Publik UGM. Vol. 8. ( 2 ): 15-31.

Mahulae, Hendra. 2017. "Melawan Teknokrasi Negara: Menggagas Perencanaan Pembangunan Lokal Berbasis Solidaritas Rakyat". Kelompok Kerja Gambut UNDP-BRGFak. Kehutanan UGM. 2 Februari.

Manurung, Martin, (ed). 2011. "Melacak Jejak dan Prospek Sosial Demokrasi Indonesia ".Jurnal Sosial-Demokrasi. Vol. 11 ( 4 ) : 4-7.

Nugraha, Setiawan. 1995. Satu Abad Transmigrasi di Indonesia. Jakarta: Djambatan.

Nugroho, Agung, (ed). 2008."Mengakhiri Rezim Konflik Kehutanan: Momentum Pasca Keputusan Mahkamah Konstitusi. " Darurat Hutan Indonesia: 50 Tahun Fakultas Kehutanan Universitas Gadjah Mada, Tangerang: Wana Aksara.

Luthfi, Nashih, Razif, Fauzi. 2008. Kronik Agraria Indonesia. Yogyakarta: STPN Press.

Pace, David. 1978. " Structuralism in History and the Social Sciences ". American Quarterly. J-Stor. Vol 3. ( 3 ): 282-297.

Ratminto, Atik. dan Septi Winarsih. 2006. Manajemen Pelayanan Publik. Yogyakarta: Pustaka Pelajar.

Sahlin, Marshall. 1976. Stone Age Economics. London: Tavistock Publications.

Safitri, M.A. dan Arizona, ed. 2011. Menuju Kepastian dan Keadilan Tenurial. Riau: Kelompok Masyarakat Sipil Untuk Reformasi Tenurial.

Spicker, Paul. 1988. Principles of Social Welfare. California: Routledge. 
Jurnal Pemikiran Sosiologi Volume 5 No. 1, 2018

Konflik Tenurial di Pulau Padang dan Isolasi Ekonomi Lokal

Ahmad Ar Rozy, Rio Belvage, dan Oka Karyanto

Strauss, Anselm. dan Corbin, Lisa. 2013. Dasar-dasar Penelitian Kualitatif. Terjemahan Shodiq \& Muttaqien. Yogyakarta: Pustaka Pelajar.

Sumardjono, Maria. 2017. " RUU Pertanahan dan UUPA “. Harian Kompas. 29 September.

Thorburn, Craig, and Christian Kull. 2015. Peatlands and Plantations in Sumatra, Indonesia: Complex Realities for Resource Governance, Rural Development and Climate Change Mitigation. Bogor: Cifor.

Tim Mediasi Pulau Padang. 2011. "SK Menhut". Kementerian Kehutanan, SK.736 Menhut-II.

\section{Sumber Media (Cetak dan Online)}

Harian Kompas, 2002. "PT RAPP Disinyalir Tampung Kayu Ilegal “: 5-2

"History about April". (http://aprilasia.com) Diakses pada 26 Januari 2018.

Life Mosaic, "Dibalik Kertas" (https://youtu.be/Ss8e49fgE3l). Diakses pada 15 Mei 2014. 